\title{
GROWTH AND YIELD OF EVEN-AGED Cupressus lusitanica PLANTATIONS IN SOUTHERN BRAZIL
}

\author{
Mário Dobner Jr. \\ Universidade Federal de Santa Catarina, Departamento de Agricultura, Biodiversidade e Florestas, Curitibanos, Santa Catarina, Brasil - \\ mario.dobner@ufsc.br \\ Received for publication: 10/07/2020 - Accepted for publication: 17/04/2021
}

\begin{abstract}
Resumo
Crescimento e produção de plantios equiâneos de Cupressus lusitanica no sul do Brasil. A silvicultura no sul do Brasil demanda espécies adicionais para uma maior diferenciação do mercado, ofertando madeira de alta qualidade e exploração de nichos específicos. Cupressus lusitanica há tempo tem seu potencial reconhecido, entretanto, até o momento, não teve seu desempenho devidamente quantificado em termos de crescimento e produção de uma forma robusta e regional. Foi objetivo deste estudo coletar e processar dados quantitativos de todos os talhões conhecidos de C. lusitanica no sul do Brasil. Inventários foram realizados (60 ha, 6-39 anos de idade) com o objetivo de modelar o desenvolvimento da altura e diâmetro dominante $\left(\mathrm{h}_{100}, \mathrm{~d}_{100}\right)$, área basal e volume comercial. A altura dominante foi a base para a avaliação da qualidade dos sítios, fornecendo curvas de índice de sítio que, juntamente com o volume comercial de talhões, permitiram a modelagem da produção. Uma grande amplitude de crescimento em altura dominante foi detectada (10-30 m aos 20 anos de idade), indicando elevada variação na qualidade dos sítios. Aos 20 anos de idade, volume comerciais entre 110 e 620 $\mathrm{m}^{3} \mathrm{ha}^{-1}$ foram observados para índices de sítio de 14 e 26 , respectivamente, equivalente a uma produtividade máxima de 6-31 $\mathrm{m}^{3} \mathrm{ha}^{-1}$ ano $^{-1}$ aos 16-18 anos de idade. Os resultados demonstraram de uma forma robusta que C. lusitanica possui alto potencial para cultivo no sul do Brasil. Desta forma, oferecendo a oportunidade de diferenciação do mercado por meio da promoção de nichos que demandam madeira para usos sólidos especiais. Palavras-chave: Cipreste; Cipreste mexicano; Produção de madeira; Manejo Florestal.
\end{abstract}

\begin{abstract}
Plantation forestry in southern Brazil demands additional timber species to a higher market differentiation by providing high quality timber and exploitation of market niches. Cupressus lusitanica has long been recognized for this purpose but, until now, it was not properly region-wide quantified in terms of growth and yield. The present study delivers the lacking quantitative approach, which may encourage the commercial use of the species. With this study it was aimed at collecting and processing quantitative data from all known $C$. lusitanica stands in southern Brazil. Inventories were carried out (60 ha, 6-39 years of age) in order to model the development of dominant height $\left(\mathrm{h}_{100}\right)$, basal area, volume and dominant diameter $\left(\mathrm{d}_{100}\right)$. Dominant height was the basis for site quality evaluation, delivering site index curves, which, together with the commercial volume of the stands, allowed yield modelling. A wide amplitude of dominant height growth was detected (10-30 $\mathrm{m}$ at 20 years), indicating a great site quality variation. At age of 20 years, commercial volumes of 110 and $620 \mathrm{~m}^{3}$ $\mathrm{ha}^{-1}$ were observed for site indexes of 14 and 26, respectively, equivalent to a maximum of 6-31 $\mathrm{m}^{3} \mathrm{ha}^{-1} \mathrm{year}^{-1}$ at ages between 16-18 years. Results demonstrated in a robust manner that $C$. lusitanica has a high potential for cultivation in southern Brazil. Thus, offering the opportunity of market differentiation by promoting market niches whose demands timber for special solid end-uses.

Keywords: Cypress; Mexican cypress; Timber production; Forest Management.
\end{abstract}

\section{INTRODUCTION}

Cupressus lusitanica Mill., also known as Mexican cypress, is a conifer native to the mountains of Central America, at altitudes varying between 1,700-4,000 m (FARJON; FILER, 2013). According to the same author, many wild stands were severely depleted for their fine timber.

The timber of $C$. lusitanica can be considered medium density structural and general purpose (ELZAKI; KHIDER, 2013). It has high dimensional stability and is suitable for special solid end-uses (MILLER; KNOWLES, 1996; OKINO et al., 2010; ALMEIDA et al., 2017), having the finest grain between conifers which deliver high quality finishing, being also naturally resistant to fungal decay and insects, which implies in 10-15 years of ground life for heartwood and well over 15 years for above ground uses (MILLER; KNOWLES, 1996). Beyond the highquality timber, the species is fast growing and relatively resistant to canker. As a result, it has been widely planted for timber production in many warm temperate and subtropical regions throughout the world (WATT et al., 2009), for example, Costa Rica (MOYA; MUNOZ, 2010), Portugal (HODOUSEK et al., 2017), Sudan (ELZAKI; KHIDER, 2013), Ethiopia (BERHE et al., 2013), Kenya (NGUGI et al., 2000), and, with growing importance in New Zealand, since cypress canker has limited plantations with Cupressus macrocarpa Hartw. (DUNGEY et al., 2013). Mean annual increments varying between $3-36 \mathrm{~m}^{3} \mathrm{ha}^{-1} \mathrm{year}^{-1}$ are reported in all these countries. 
In southern Brazil, $C$. lusitanica has long been indicated for cultivation in the highlands (SHIMIZU et al., 1995). This region has an established planted-forest-based sector, mainly supplied by Pinus taeda L (1,5 million ha) (EISFELD; NASCIMENTO, 2015; ACR, 2019; IBÁ, 2019). The predominance of $P$. taeda is due to growth rates $\left(34 \mathrm{~m}^{3} \mathrm{ha}^{-1}\right.$ year ${ }^{-1}$ at age of $\sim 15$ years in average), adaptability to the edaphoclimatic conditions and versatility to a wide range of end-uses (ACR, 2019). Although P. taeda is responsible for a successful forest sector, there is an unquestionable need for increasing diversity. Diversity in this context means additional timber species to a higher market differentiation by providing high quality timber with complementary wood properties and thus, allowing exploitation of market niches. Market differentiation might be also faced as risks reduction imposed by a largely based single-specie sector.

According to Dobner Jr. et al. (2018), the species is not commercially used in southern Brazil due to lack of reliable genetic material. The authors reached this conclusion after visiting several stands where a great variability of growth and quality was observed. Additionally, it is hypothesized that a further reason for not commercially regarding the species is the absence of robust quantitative information of growth and yield. Indeed, growth and yield knowledge about $C$. lusitanica grown in southern Brasil was restricted to a few small experimental plots. With this study it was aimed at collecting and processing quantitative data from all known $C$. lusitanica stands in southern Brazil and thus, providing a robust quantitative approach within the existing variability. Site index analysis as well as yield modelling of commercial stands are presented.

\section{MATERIAL AND METHODS}

\section{Study site}

The study was conducted in the highlands of southern Brazil (800-1,000 m a.s.l), where the climate is humid, subtropical, oceanic, without dry season and with temperate summer (Cfb, after Köppen classification). The region has an average annual precipitation of 1,600-1,900 mm and a mean annual temperature of $12-16{ }^{\circ} \mathrm{C}$ (ALVARES et al., 2013). Severe frosts occur.

Data was collected in seven different municipalities, across the highland of the Santa Catarina state (Tab. 1 and Fig. 1). Extreme sampling places were $250 \mathrm{~km}$ distant from each another. In total $\sim 60$ ha of $C$. lusitanica stands were considered in this study, with ages varying between 6-39 years.

Table 1. Sampling regions are listed according to their municipality name. The number of stands, number of plots, planted area, the age span and stand density span per region are also given.

Tabela 1. Regiões de amostragem listadas de acordo com o nome do município. O número de talhões, número de parcelas, área plantada, amplitude de idades e amplitude de densidade dos talhões em cada região são também apresentados.

\begin{tabular}{lccccc}
\hline \multicolumn{1}{c}{ Municipality } & Number of stands & Number of plots & $\begin{array}{c}\text { Area } \\
\text { (ha) }\end{array}$ & $\begin{array}{c}\text { Age } \\
\text { (years) }\end{array}$ & $\begin{array}{c}\text { N } \\
\text { (trees ha }{ }^{-1} \text { ) }\end{array}$ \\
\hline CBS - Campo Belo do Sul & 19 & 26 & 27 & $6-24$ & $610-1,460$ \\
CA - Capão Alto & 2 & 3 & 5 & $9-19$ & $630-1,590$ \\
SJC - São José do Cerrito & 2 & 8 & 15 & $12-17$ & $860-1,120$ \\
CP - Correia Pinto & 2 & 2 & 3 & $8-16$ & $1,310-1,520$ \\
CTB - Curitibanos & 1 & 2 & $<1$ & $7-8$ & 1,050 \\
CA - Caçador & 1 & 5 & 6 & 39 & 410 \\
RN - Rio Negrinho & 2 & 4 & 3 & $17-20$ & $490-930$ \\
\hline \multicolumn{1}{c}{ Total } & 29 & 50 & 60 & $6-39$ & $410-1,590$ \\
\hline
\end{tabular}




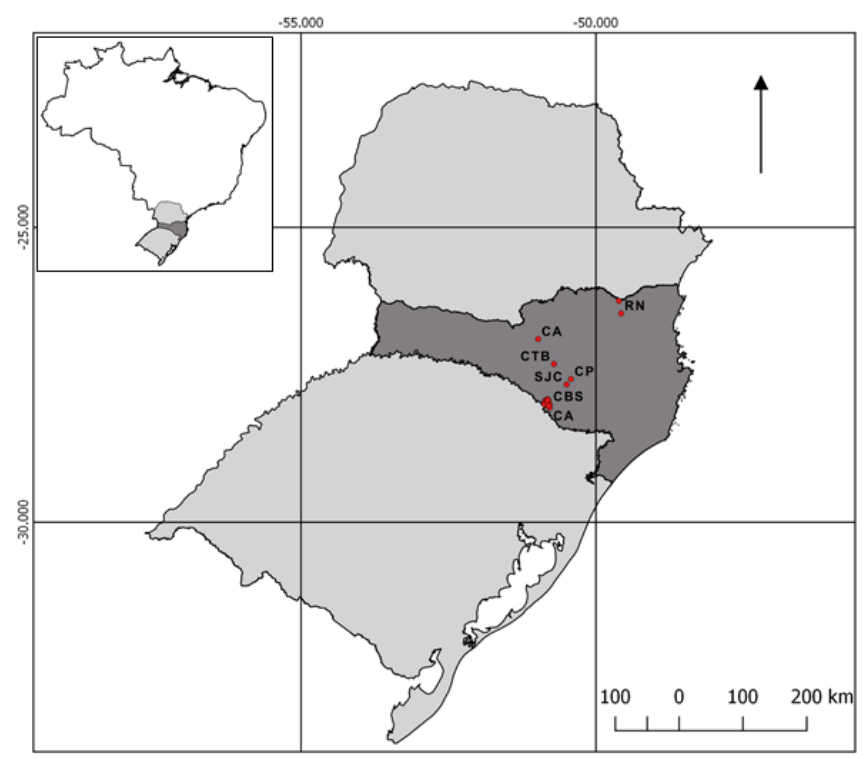

Figure 1. Sampling places in southern Brazil (light grey) according to their municipality names as given in Tab. 1. The state of Santa Catarina is dark grey highlighted.

Figura 1. Locais de amostragem no sul do Brasil (cinza claro), indicados de acordo com o nome do município apresentado na Tab. 1. O estado de Santa Catarina está destacado em cinza escuro.

Stands were established with 1,600-2,000 trees $\mathrm{ha}^{-1}$, reaching different densities at sampling ages due to natural mortality or light thinnings from below (Tab. 1).

\section{Data collection and analysis}

Inventories were carried out in 2014, 2016 and 2019, thus plots $\left(500 \mathrm{~m}^{2}\right)$ were measured up to three times. Some of them, however, had two or only one measurement since stands were more recently discovered. Measured variables were: (1) diameter at breast height over bark $(d b h, 1,3 \mathrm{~m})$, measured with a diametric tape to the closest millimeter; (2) tree height $(h)$, randomly measured over the diametric range, including the dominant trees (the 100 trees with the biggest $d b h$ per ha) and the smallest one, at least 10 trees per plot, with the hypsometer Vertex IV (Haglöf $\AA$, Sweden); (3) diameter $\left(d_{\mathrm{i}}\right)$ at different heights $\left(h_{\mathrm{i}}=0.1,0.5,1.0,1.5\right.$ and $2.0 \mathrm{~m}$ and, from this height onwards in $2 \mathrm{~m}$ intervals) with caliper to the closest millimeter (scaling). The scaling measurements were conducted in three stands with ages of 8 (34 trees, $d b h 5-21 \mathrm{~cm}), 12(26$ trees, $d b h 7-33 \mathrm{~cm})$ and 16 years $(28$ trees, $d b h 21-50 \mathrm{~cm}$ ) in the regions of CBS and SJC (Tab. 1, Fig. 1). Unfortunately, it was not possible to proceed destructive scaling in older stands. Inventory and scaling data were used to fit hypsometric models, per stand and age, and taper models (Kozak and the $5^{\text {th }}$ degree polynomial), for the scaled ages, both by linear regression techniques. Additionally, the artificial form factor $\left(f_{1.3}\right)$ was obtained dividing the tree volume by the volume of a hypothetical cylinder formed by the $d b h$ and $h$. For commercial volume estimations, the fitted taper equation with age closer to the stand was regarded.

Dominant height $\left(\mathrm{h}_{100}\right)$ and dominant diameter $\left(\mathrm{d}_{100}\right)$ development were assessed by using a time series of paired values to fit the three parametric Richards growth model (Eq. 1), with non-linear least square technique, where $a, b$ and $c$ are the model parameters and $A$ is age:

$$
y=a \times\left(1-e^{-b \times A}\right)^{c}
$$

In both cases, models were fit based on the dataset with ages varying between 6-39 years. Dominant height was the base for site quality evaluation, delivering site index curves with help of the guide curve method. Dominant diameter development was than fitted regarding only average site classes. Statistical analysis was performed using RStudio version 1.1.383 (R Core Team, 2017). Statistical significance was assessed at $\alpha=0.05$.

In order to quantify $\log$ assortment volumes, logs with $2.5 \mathrm{~m}$ in length were classified based on their small-end diameter (SED) over bark in 10-cm-wide classes. This quantification was carried out with help of Florexel (Optimber®). Then, the total commercial volume (SED $\geq 10 \mathrm{~cm}$ ) of unthinned stands was employed for growth and yield modelling with help of the compatible model of Sullivan and Clutter (1972):

where: $A_{1}=$ initial age in years

$$
\begin{gathered}
\ln B_{2}=\ln B_{1}\left(\frac{A_{1}}{A_{2}}\right)+\alpha_{0}\left(1-\frac{A_{1}}{A_{2}}\right)+\alpha_{1} S\left(1-\frac{A_{1}}{A_{2}}\right) \\
\ln V_{2}=\beta_{0}+\beta_{1} S+\beta_{2} A_{2}^{-1}+\beta_{3} \ln B_{2}
\end{gathered}
$$


$A_{2}=$ projection age in years

$B_{1}=$ initial basal area in $\mathrm{m}^{2} \mathrm{ha}^{-1}$

$B_{2}=$ the predicted basal area at age $A_{2}$ in $\mathrm{m}^{2} \mathrm{ha}^{-1}$

$S=$ site index

$V_{2}=$ predicted volume at age $A_{2}$ in $\mathrm{m}^{3} \mathrm{ha}^{-1}$

$\alpha_{i s}$ and $\beta_{\text {is }}$ are the model parameters

\section{RESULTS}

\section{Taper equations}

The taper equations fitted for $C$. lusitanica with 8,12 and 16 years of age grown in southern Brazil are given as follow. The best fit was obtained for the $5^{\text {th }}$ degree polynomial model for all ages, delivering the best coefficients of determination $\left(\mathrm{R}^{2}\right), 0.95,0.96,0.94$, respectively.

$$
\begin{aligned}
& 8 \text { yrs } \frac{d_{\mathrm{i}}}{d b h}=1.327-4.618\left(\frac{h_{\mathrm{i}}}{h_{t}}\right)+24.653\left(\frac{h_{\mathrm{i}}}{h_{t}}\right)^{2}-63.294\left(\frac{h_{\mathrm{i}}}{h_{t}}\right)^{3}+68.184\left(\frac{h_{\mathrm{i}}}{h_{t}}\right)^{4}-26.357\left(\frac{h_{\mathrm{i}}}{h_{t}}\right)^{5} \\
& 12 \text { yrs } \frac{d_{\mathrm{i}}}{d b h}=1.227-3.339\left(\frac{h_{\mathrm{i}}}{h_{t}}\right)+13.423\left(\frac{h_{\mathrm{i}}}{h_{t}}\right)^{2}-29.166\left(\frac{h_{\mathrm{i}}}{h_{t}}\right)^{3}+26.843\left(\frac{h_{\mathrm{i}}}{h_{t}}\right)^{4}-9.011\left(\frac{h_{\mathrm{i}}}{h_{t}}\right)^{5} \\
& \mathbf{1 6} \text { yrs } \frac{d_{\mathrm{i}}}{d b h}=1.245-4.328\left(\frac{h_{\mathrm{i}}}{h_{t}}\right)+16.919\left(\frac{h_{\mathrm{i}}}{h_{t}}\right)^{2}-34.246\left(\frac{h_{\mathrm{i}}}{h_{t}}\right)^{3}+30.542\left(\frac{h_{\mathrm{i}}}{h_{t}}\right)^{4}-10.199\left(\frac{h_{\mathrm{i}}}{h_{t}}\right)^{5}
\end{aligned}
$$

where: $\quad d b h=$ diameter at breast height in $\mathrm{cm}$

$d_{\mathrm{i}}=$ diameter in $\mathrm{cm}$ measured at height $\mathrm{h}_{\mathrm{i}}$

$h_{\mathrm{i}}=$ height along bole in $\mathrm{m}$

$h_{\mathrm{t}}=$ total height in $\mathrm{m}$

These are probably the first taper models for $C$. lusitanica grown in Brazil, since no previous studies with this approach could be found. A graphic representation of the taper equations is presented in Fig. 2, where the expected trend of decreasing tapering with age can be observed.

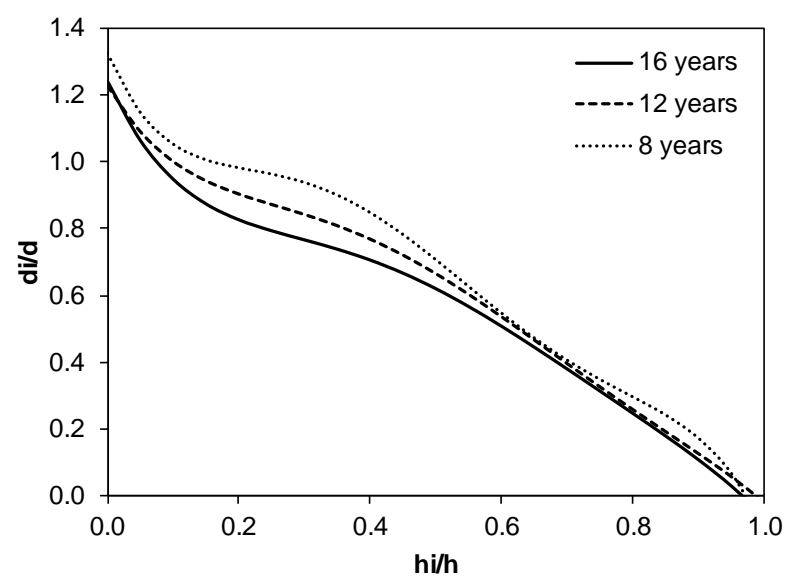

Figure 2. Graphic representation of the fitted taper equations for C. lusitanica grown in southern Brazil with 8 , 12 and 16 years of age, Eq. 4, 5 and 6, respectively.

Figura 2. Representação gráfica das equações de afilamento ajustadas para $C$. lusitanica plantadas no sul do Brasil com 8, 12 e 16 anos de idade. Eq. 4, 5 e 6, respectivamente.

The artificial form factor $\left(f_{1.3}\right)$ for each taper equation are $0.539,0.467$ and 0.415 , for the ages 8,12 and 16 years, respectively.

\section{Site index}

Dominant height $\left(\mathrm{h}_{100}\right)$ paired with age values was the base of the site quality evaluation. In total, 151 pairs were employed to fit the guide curve shown as follow $\left(\mathrm{R}^{2}=0.73, \mathrm{~S}_{\mathrm{yx}}=2.8 \mathrm{~m}\right.$ or $\left.18.3 \%\right)$ and in Figure 3-a. With help of the guide curve and the dominant height amplitude observed at ages of 18-20 years (20 years as index age), site index curves were obtained (Figure 3-b).

$$
\begin{aligned}
h_{100} & =27.017\left[1-e^{-0.078 \times \text { Age }}\right]^{1.368} \\
S & =h_{100}\left[\frac{1-e^{-0.078 \times \text { Index age }}}{1-e^{-0.078 \times \text { Age }}}\right]^{1.368}
\end{aligned}
$$


From Figure 3-a it can be observed the wide amplitude of dominant height growth of $C$. lusitanica in southern Brazil (10-30 m), which indicate a great variation in site quality. Values of $h_{100}>25 \mathrm{~m}$ were observed at two locations, CBS and RN (Tab. 1 and Fig. 1).

Fitted site index curves present three site classes named 14, 20 and 26, the dominant height at age of 20 years, respectively, used as reference for further analyses.
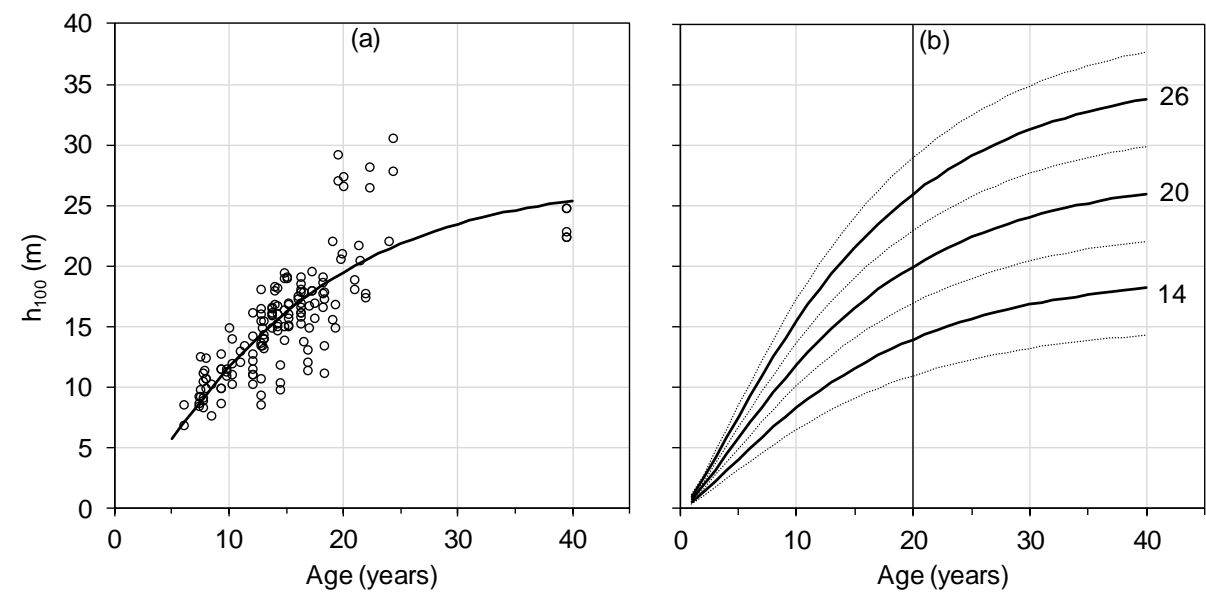

Figure 3. (a) Guide curve of dominant height growth, Eq. 7 and (b) site index curves, Eq. 8, for C. lusitanica grown in southern Brazil. Dotted line represents site classes boundaries while the full line indicates the average dominant height growth for the respective site index.

Figura 3. (a) curva guia do crescimento em altura dominante, Eq. 7 e (b) curvas de índice de sítio, Eq. 8, para $C$. lusitanica plantado no sul do Brasil. A linha pontilhada representa os limites das classes de sítio, enquanto a linha cheia indica o crescimento médio em altura dominante para o respectivo índice de sítio.

\section{Basal area growth and volume yield}

With help of the site index previously shown, a yield model was fitted, firstly to predict future basal area as a function of site quality, age and initial basal area $\left(\mathrm{R}^{2}=0.96, \mathrm{~S}_{\mathrm{yx}}=1.8 \mathrm{~m}^{2} \mathrm{ha}^{-1}\right.$ or $\left.7.7 \%\right)$. Secondly, with the predicted basal area, the predicted commercial volume $(\mathrm{SED} \geq 10 \mathrm{~cm})$ was also estimated $\left(\mathrm{R}^{2}=0.96, \mathrm{~S}_{\mathrm{yx}}=21.4 \mathrm{~m}^{3}\right.$ $\mathrm{ha}^{-1}$ or $\left.12.1 \%\right)$. Fitted equations are given as follow. Predicted compared to observed values, as an indicator of fitting quality, are shown in Fig. 4.

$$
\begin{gathered}
\ln B_{2}=\ln B_{1}\left(\frac{A_{1}}{A_{2}}\right)+2.356\left(1-\frac{A_{1}}{A_{2}}\right)+0.079 S\left(1-\frac{A_{1}}{A_{2}}\right) \\
\ln V_{2}=1.239+0.058 S-9.026 A_{2}^{-1}+1.022 \ln B_{2}
\end{gathered}
$$
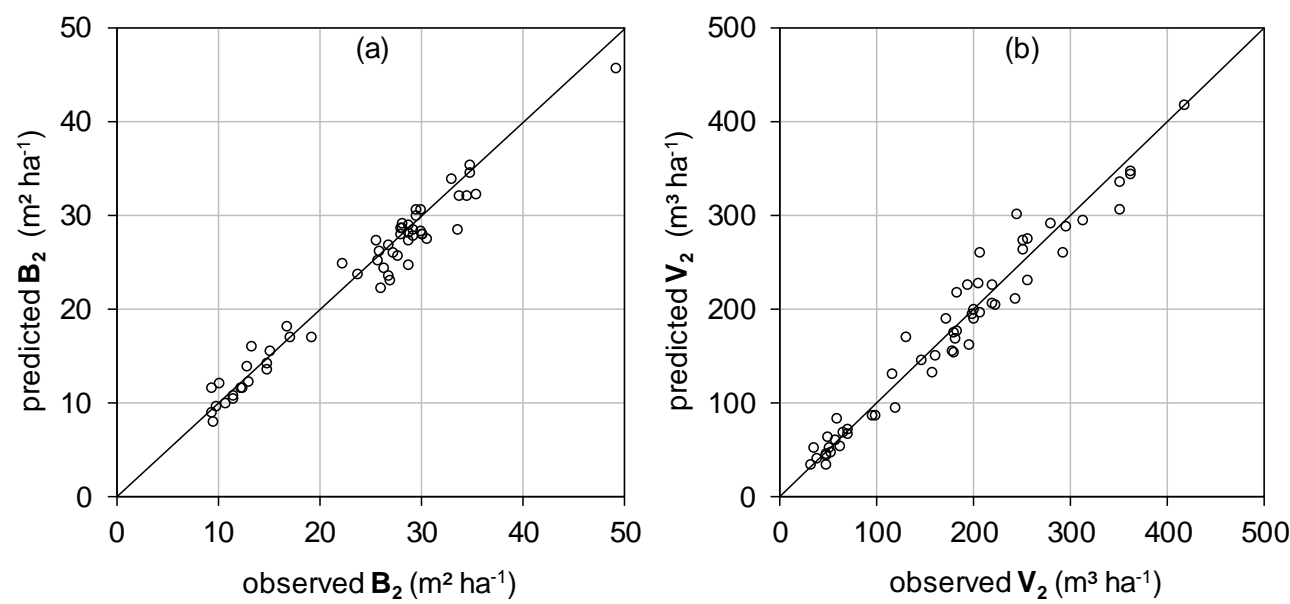

Figure 4. Predicted compared to observed values for (a) basal area, Eq. 9, and (b) commercial volume (SED $\geq 10$ $\mathrm{cm})$, Eq. 10, of C. lusitanica grown in southern Brazil.

Figura 4. Valores preditos comparados com os observados para (a) área basal, Eq. 9, e (b) volume comercial (dpf $\geq 10 \mathrm{~cm}$ ), Eq. 10, para C. lusitanica cultivado no sul do Brasil. 
The fitted yield models can then be used for a better understanding of the real yield potential of $C$. lusitanica in southern Brazil. The average basal area growth and commercial volume yield for different site indexes are given in Fig. 5.
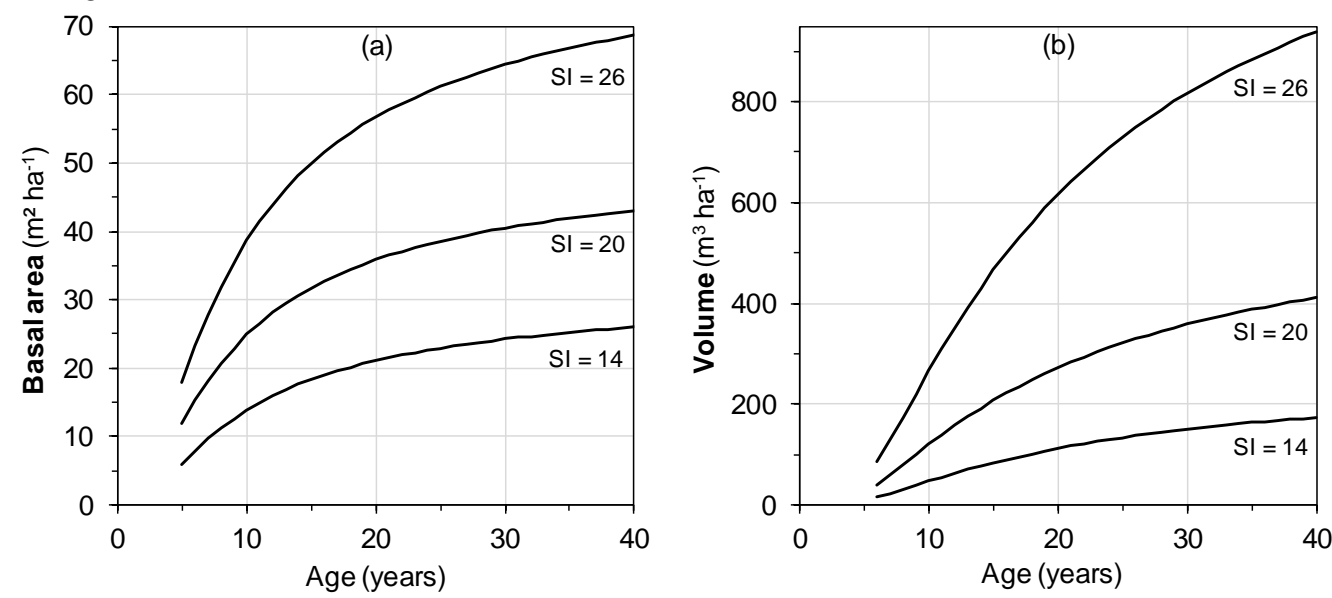

Figure 5. Predicted (a) basal area and (b) commercial volume ( $\operatorname{SED} \geq 10 \mathrm{~cm}$ ) for C. lusitanica grown in southern Brazil at three different site indexes, obtained with help of the equations 9 and 10, respectively.

Figura 5. (a) Área basal e (b) volume comercial $(\mathrm{dpf} \geq 10 \mathrm{~cm})$ preditos para $C$. lusitanica cultivado no sul do Brasil em três diferentes índices de sítio, obtidos com o auxílio das equações 9 e 10, respectivamente.

The great site quality differences already verified in terms of dominant height is even more evident when basal area and volume development are regarded. At age of 20 years, a $C$. lusitanica stand grown at SI=14 will reach a basal area of only $21 \mathrm{~m}^{2} \mathrm{ha}^{-1}$, while one at $S I=26$ could deliver $57 \mathrm{~m}^{2} \mathrm{ha}^{-1}$. Commercial volume yield curves reinforce this since differences between site indexes are even more disproportionate. A stand at $S I=14$ delivered only $110 \mathrm{~m}^{3} \mathrm{ha}^{-1}$ at age of 20 years, while $S I=20$ delivered $270 \mathrm{~m}^{3} \mathrm{ha}^{-1}$ and $S I=26$ as much as $620 \mathrm{~m}^{3} \mathrm{ha}^{-1}$, additional yield of 160 and $350 \mathrm{~m}^{3} \mathrm{ha}^{-1}$, respectively. In terms of mean annual increment, these three site indexes were able to deliver a maximum of 5.6, 13.8 and $31.3 \mathrm{~m}^{3} \mathrm{ha}^{-1}$ year $^{-1}$ at ages between 16-18 years. Current annual increment in volume peaked for all site indexes at age of 9 years, with values varying between $8-46 \mathrm{~m}^{3} \mathrm{ha}^{-1}$ year $^{-1}$, showing the pioneer behavior of the species.

\section{Dominant diameter growth}

For the dominant-diameter-growth modelling, only data from plot classified as site indexes between 1822 were regarded and thus, representing an average site quality $(S I=20, \mathrm{n}=318)$. The fitted equation is given below $\left(\mathrm{R}^{2}=0.78, \mathrm{~S}_{\mathrm{yx}}=4.4 \mathrm{~m}\right.$ or $\left.15.9 \%\right)$. All parameters were obtained with high significance $(p<0.001)$. Data and fitted curve are given in Fig. 6.

$$
d_{100}=66.807\left[1-e^{-0.046 \times A g e}\right]^{1.187}
$$

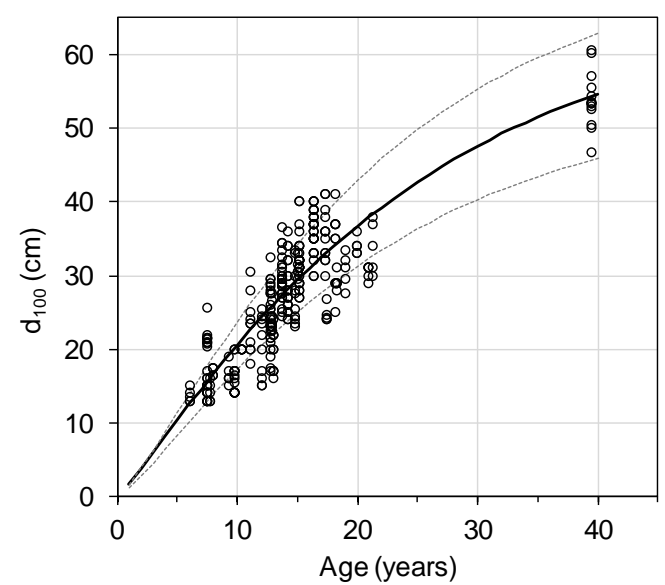

Figure 6. Dominant diameter growth for $C$. lusitanica in southern Brazil. Full line indicates the average growth obtained with help of the fitted Eq. 11. Dashed lines indicate a probable growth amplitude along time. 
Figura 6. Crescimento em diâmetro dominante para C. lusitanica cultivado no sul do Brasil. A linha cheia indica o crescimento médio obtido com o auxílio da Eq. 11. As linhas pontilhadas indicam uma amplitude provável de crescimento ao longo do tempo

In Fig. 6 it can be observed that, considering the current genetic basis and management standard, 30-35years of production cycle will deliver, in average site conditions, dominant diameters of $\sim 50 \mathrm{~cm}$. However, higher growth levels as a result of genetic breeding and better management practices could deliver the same dominant diameter in production cycles of $\sim 25$ years.

\section{DISCUSSION}

\section{Taper}

Taper models were successfully fitted, which, in terms of artificial form factor $\left(f_{1.3}\right)$ indicated and increasing tapering with age, i.e. decreasing $f_{1.3}$ values with increasing age. Noteworthy is that the taper analysis regarded relatively young trees, up to 16 years of age. It is expected that $f_{1.3}$ would increase if older trees were regarded. A similar pattern was observed for Araucaria angustifolia by Martins et al. (2017), when young trees showed a higher $f_{1.3}$ because of the proximity of $d b h$ to total height which, for $C$. lusitanica was particularly important because of the strong tapering at tree base, as observed in Fig. 2.

\section{Site index}

The range of dominant height across southern Brazil showed that height growth, i.e. site quality, varied widely between stands (10-30 m at age 20 years). The best sites were observed both at the southernmost and northernmost regions, CBS and RN (Tab. 1, Fig. 1), indicating that the whole studied region has favorable edaphoclimatic conditions for cultivating $C$. lusitanica and that microsite variations together with genetic materials are responsible for the great amplitude of growth potential. Both stands with higher $h_{100}$ were established with seeds from Colombia, indicating that this is a provenance of high growth potential in southern Brazil, as already reported by Shimizu et al. (1995).

Slightly lower values at age of 20 years were reported by Berril (2004) for C. lusitanica grown in New Zealand. However, when the age of 30 years is regarded, values are identical to the ones observed in the present study, $15 \mathrm{~m}$ for poor sites and $35 \mathrm{~m}$ for very good ones. According to Miller and Knowles (1996), on good sites in New Zealand, $C$. lusitanica at 40 years may reach heights of $30 \mathrm{~m}$, which is in line with the performance observed in the upper level of site index classification presented for southern Brazil. Altogether, it can be concluded that growth potential of the species in New Zealand is comparable to the one in southern Brazil.

A similar range of dominant height was also reported by Teshome and Petty (2000) for C. lusitanica in Ethiopia, where site classes with values between 13-30 m at age of 20 years were described.

Ngugi et al. (2000) reported for $C$. lusitanica grown in Kenya, dominant heights at age of 20 years between 20-30 m. Similar to the ones described by Mamo and Sterba (2006) in Ethiopia for the same age, where dominant height amplitudes of 20-35 m were observed. These values match with the upper level described in the present study, been also slightly higher in Kenya, and both with less variation than the ones measured in southern Brazil. However, Pukalla and Phojonen (1993), also for Ethiopia, found a dominant height amplitude of 15-20 m at age of 20 year, which, in comparison to the ones observed in Brazil, are at a middle low level.

One important aspect in this regard is that, at least in CBS and CA (southern Brazil, Tab. 1 and Fig. 1), where the majority of $C$. lusitanica stands were sampled for the present study, many of them were established on shallow soils, based on the reported ability of the species to grow in poor sites. As a result, growth is obviously low. Yet, one of the best site qualities for southern Brazil was also observed in CBS, as already mentioned - most circles at a disproportional higher level in Fig. 3-a. Indeed, shallow soils are the most frequent and obvious limitation to growth of plantation forestry in the highlands of southern Brazil, as already reported for P. taeda (Horst et al., 2018). Besides this general idea, further studies should invest in understanding which site variables are the driving factor for $C$. lusitanica growth and yield in order to avoid the poorest ones that deliver as low as $10 \mathrm{~m}$ of dominant height at 20 years of age. Nevertheless, being these sites with shallow soils marginal to the majority of soil uses, it should also be verified if, indeed, $C$. lusitanica is able to comparatively use it in an effective way.

For comparison purpose, the dominant height amplitude for $P$. taeda grown in southern Brazil is 16-31 $\mathrm{m}$ at age of 20 years (SCHUCHOVSKI et al., 2019). The average value of $h_{100}$ for $P$. taeda at age of 15 years is $22 \mathrm{~m}$ (default in Sispinus, the most used growth and production simulator), which, compared to the curve of SI 26 , (at age of 15 years, $h_{100}=22 \mathrm{~m}$ ) indicate that, in terms of dominant height, $C$. lusitanica cultivated in high quality sites and with appropriate genetic material presents comparable growth potential to the average one obtained with P. taeda. 


\section{Basal area growth and volume yield}

Additional to dominant height development, basal area is an important feature in forest management, delivering even more robust insights in relation to yield and scheduling silvicultural practices. The fact that basal area at age 20 years varies between 20-55 $\mathrm{m}^{2} \mathrm{ha}^{-1}$ shows the impressive effect of site quality on the growth of $C$. lusitanica grown in southern Brazil. In Kenya, basal area between 40-50 $\mathrm{m}^{2} \mathrm{ha}^{-1}$ at age of 20 years are reported for unthinned $C$. lusitanica stands (NGUGI et al., 2000) showing that, in terms of basal area, the best sites of southern Brazil are comparable to the ones in Kenya.

Volume yield, however, is the key variable. Maximum mean annual increments observed for C. lusitanica in southern Brazil varied between 6-31 m $\mathrm{ha}^{-1}$ year ${ }^{-1}$ at ages of 16-18 years. Yield between 10-36 $\mathrm{m}^{3} \mathrm{ha}^{-1} \mathrm{year}^{-1}$ have already been reported by Shimizu et al. (1995) for Brazil, the best one obtained by progenies from Colombia and the lowest ones by local seed source (Camanducaia, MG). Thus, indicating that genetic material may also play an important role in the wide range of observed yield. Unfortunately, only few studied stands have some information about their genetic provenance and, therefore, no further discussion can be supported in this regard. It indicates, however, that more attention to the seed source should be regarded.

Pukalla and Pohjonen (1993) reported yields between 6-17 $\mathrm{m}^{3} \mathrm{ha}^{-1}$ year ${ }^{-1}$ for $C$. lusitanica in Ethiopia in rotation length ranging from 25 (best sites) to 34 years (poorest sites). The authors pointed out that proper management of plantations at that time were neglected. Berril (2004) mentioned the same values $\left(6-17 \mathrm{~m}^{3} \mathrm{ha}^{-1}\right.$ year $^{-1}$ ) at ages of 15-30 years in New Zealand, however, with one single record of $36 \mathrm{~m}^{3} \mathrm{ha}^{-1} \mathrm{year}^{-1}$.

Standing volumes between $100-600 \mathrm{~m}^{3} \mathrm{ha}^{-1}$ at 20 years of age for full stoked stands were observed as a result of site quality in southern Brazil. Noteworthy is that stands with only $100 \mathrm{~m}^{3} \mathrm{ha}^{-1}$ are substantially and negatively influenced by exposed bedrocks, a physical impediment which reduces soil and water availability, the number of cultivated trees and obviously yield. Stands of $C$. lusitanica in New Zealand around 20 years of age showed stockings ranging from 240-1,000 trees ha-1, with total standing volumes between $160-650 \mathrm{~m}^{3} \mathrm{ha}^{-1}$ and current annual increments of 17-58 $\mathrm{m}^{3} \mathrm{ha}^{-1}$ year $^{-1}$. By comparison, mature (>40 years) and unthinned stands of $C$. macrocarpa usually maintain very high stocking levels (1,200-1,300 trees ha $\left.{ }^{-1}\right)$, carrying total standing volumes as high as 1,000-1,600 $\mathrm{m}^{3} \mathrm{ha}^{-1}$, still growing with exceptional current annual increment of 30-70 $\mathrm{m}^{3} \mathrm{ha}^{-1} \mathrm{year}^{-1}$. On poor sites, by contrast, stands are dismal in performance with total volumes at similar ages of no more than 200$450 \mathrm{~m}^{3} \mathrm{ha}^{-1}$ (MILLER; KNOWLES, 1996).

Average mean annual increments for $P$. taeda cultivated in southern Brazil are $34 \mathrm{~m}^{3} \mathrm{ha}^{-1}$ year-1 at age of $\sim 15$ years (ACR, 2019), once again, the values of $\sim 30 \mathrm{~m}^{3} \mathrm{ha}^{-1}$ year $^{-1}$ at age of 16-18 years observed for C. lusitanica in this study reinforces that its productivity is comparable to $P$. taeda, even if slightly lower. It is important to note that $C$. lusitanica, if regarded for timber production, would not compete for maximum volume production. Instead, it would be an option for timber production aiming at special solid end-uses with complementary wood properties (VIVIAN et al., 2020).

\section{Dominant diameter growth}

The cultivation of $C$. lusitanica is only meaningful in the context of market niches of high-quality timber, which implies big-sized logs. Therefore, individual growth assumes a greater importance than volume yield per hectare. By analyzing the dominant diameter of the stands, it is possible to evaluate individual growth of the potential crop trees. Dominant trees with $d b h$ close to $50 \mathrm{~cm}$ can be obtained in production periods of $30-35$ years regarding current genetic material and management standard. Previous study reported a substantial improvement potential from genetic material since a great variability was observed and already rescued from stands in southern Brazil (DOBNER JR. et al., 2018). Furthermore, it is noteworthy that there is no management standard for $C$. lusitanica in southern Brazil. Measured stands for the present study, probably all existing stands of this species in the region, were not consciously managed. The great majority had no thinning at all or only thinnings from below of low intensity. There was only one exception, the stand presented in Fig. 7-b, where intense thinnings from above were conducted since early ages and then, the diameter growth under appropriate management regimes can be evaluate. Fortunately, this was carried out at a very good site, expressing therefore the probable species upper threshold for the studied region.

Huss and Dobner (2020) reported for P. taeda grown in southern Brazil dominant diameter between 38$54 \mathrm{~cm}$ at 20 years of age, as a result of different planting densities and thinning intensities. The comparison provides the perception that $C$. lusitanica can only reach the bottom level verified for $P$. taeda, obtained with the highest initial density $\left(2,500\right.$ trees $\left.^{-1}\right)$ and without any thinning. However, at age of 40 years, C. lusitanica reach a $\mathrm{d}_{100}$ value $>50 \mathrm{~cm}$, similar to the one obtained from $P$. taeda stands with medium initial density $\left(1,250\right.$ trees ha $^{-}$ ${ }^{1}$ ) subjected to heavy thinnings. Thus, $C$. lusitanica in southern Brazil, even without a conscious management strategy was already able to deliver dominant diameters similar to those obtained in well managed $P$. taeda stands, reinforcing the growth potential of the species. 
Experiences in New Zealand indicate a final stocking of 400 trees ha ${ }^{-1}(5 \times 5 \mathrm{~m})$ for a final crop with of $50 \mathrm{~cm}$ and 280 trees $\mathrm{ha}^{-1}(6 \times 6 \mathrm{~m})$ for a target $d b h$ of $60 \mathrm{~cm}$ (MILLER; KNOWLES, 1996). According to the same authors, a general recommendation is $\sim 300$ potential crop trees $\mathrm{ha}^{-1}$ for the final harvest.

\section{Final considerations}

Accumulated experiences in New Zealand recommend high initial stocking $\left(1,000-2,000\right.$ trees $\left.^{-1}\right)$ to promote rapid canopy closure, suppress weeds, reduce branch size, and provide good stem form (MILLER; KNOWLES, 1996). According to the same authors, pruning should be light and frequent to avoid formation of dead knots and delivering high quality pruned button logs, which are expected to provide $40 \%$ of the final volume. In relation to management strategies such as thinning time and intensity, Teshome and Petty (2000) pointed out that a dominant height of $11 \mathrm{~m}$ may be an appropriate indicator for starting with the first thinning, which would be at ages of 6-18 years according to site quality classes obtained in the present study. Noteworthy is that the species is shallow rooting and, therefore, should not be severely thinned where windthrow can occur.

C. lusitanica is reported to be more resistant to canker, caused by Siridium unicorne and S. cardinale, than C. macrocarpa. No report for canker in C. lusitanica stands in southern Brazil was found. Anyhow, this should be kept in mind if the species increases its importance.

Despite the known uniformity of wood density, wood stiffness increases strongly from pith to bark, and so $C$. lusitanica do have a core wood problem, like most conifers. This would be greatly alleviated by longer productions periods, with the addition of more rings of outer wood. In line with this, Ngugi et al. (2000) indicate final cut age at 30 years for Kenya, while Miller and Knowles (1996) recommended 30-40 years productions cycles in New Zealand.

Results demonstrated in a robust manner that $C$. lusitanica has a high potential for cultivation in southern Brazil. However, substantial low growth and yield rates were also observed indicating that further investigations are needed to avoid such poor performance. Thus, site quality should be studied in order to identify the features driving site productivity, for example as conducted by (WATT et al., 2009) in New Zealand. Observations in Kenya and Mexico suggest the best sites for $C$. lusitanica are those where atmospheric humidity is fairly constant (MILLER; KNOWLES, 1996). Additionally, genetic breeding should guarantee a more stable population in terms of growth and quality features such as number and size of branches, stem taper, apical dominance and fluting. More studies are also needed to understand and quantify optimal stocking levels and thinning schedules for different site qualities. Finally, the timber quality of $C$. lusitanica grown in southern Brazil and its end-uses potential should also be more investigated, as well as a market analysis. These, together with the growth and yield information, provided by the present study, would allow robust economic analyses.

\section{CONCLUSION}

Results demonstrated in a robust manner that:

- $\quad$. lusitanica has a high potential for cultivation in southern Brazil, offering the opportunity of market differentiation by promoting market niches whose demands timber for special solid end-uses.

- Maximum productivities of 6-31 $\mathrm{m}^{3} \mathrm{ha}^{-1}$ year $^{-1}$ at ages between 16-18 years are to be expected depending on site quality.

- Dominant trees with $d b h$ of $50 \mathrm{~cm}$ can be obtained in production periods of 25-35 years, depending on genetic material, site quality and management practices.

\section{REFERENCES}

ACR - Associação Catarinense de Empresas Florestais. Anuário estatístico de base florestal para o estado de Santa Catarina 2019 (ano base 2018). ACR, 2019, 118 p.

ALMEIDA, C. C. F.; CUNHA, A. B.; RIOS, P. D. Quality evaluation of Cupressus lusitanica Mill. wood enfgrain glued joints for edge glued panel production. Scientia Forestalis, Piracicaba, v. 45, n. 113, p. 9 - 19, 2017.

ALVARES, C. A.; STAPE, J. L.; SENTELHAS, P. C.; GONCALVES, J. L. M.; SPAROVEK G. Koppen's climate classification map for Brazil. Meteorologische Zeitschrift, Stuttgart, v. 22, p. 711 - 728, 2013.

BERHE, L.; ASSEFA, G.; TEKLAY, T. Models for estimation of carbon sequestered by Cupressus lusitanica plantation stands at Wondo Genet, Ethiopia. Southern Forests, Makhanda, v. 75, p. 113 - 122, 2013.

BERRILL, J.-P. Preliminary growth and yield models for even-aged Cupressus lusitanica and C. macrocarpa plantations in New Zealand. New Zealand Journal of Forestry Science, Springfield, v. 34, n. 3, p. 272 - 292 , 2004. 
DUNGEY, H. S.; RUSSELL, J. H.; SILVA, J. C. E.; LOW, C. B.; MILLER, M. A.; FLEET, K. R.; STOVOLD, G. T. The effectiveness of cloning for the genetic improvement of Mexican white cypress Cupressus lusitanica (Mill.). Tree Genetics and Genomes, Alemanha, v. 9, p. 443 - 453, 2013.

EISFELD, R. L.; NASCIMENTO, F. A. F. Mapeamento dos plantios florestais do estado do Paraná: Pinus e Eucalyptus. Instituto de Florestas do Paraná, Curitiba, 2015, 76 p.

ELZAKI, O. T.; KHIDER, T. O. Physical and mechanical properties of Cupressus lusitanica as a potential timber tree for Sudan. Journal of Forest Products and Industries, Santa Clara, v. 2, n. 1, p. 43 - 46, 2013.

FARJON, A.; FILER, D. An atlas of the world's conifers: an analysis of their distribution, biogeography, diversity and conservation status. Boston: Brill, 2013, 512 p.

HODOUSEK, M.; DIAS, A.; MARTINS, C.; MARQUES, A. F. S.; BOHM, M. Comparison of Non-Destructive Methods Based on Natural Frequency for Determining the Modulus of Elasticity of Cupressus lusitanica and Populus x canadensis. Bioresources, Raleigh, v. 12, p. 270 - 282, 2017.

HORST, T. Z.; DALMOLIN, R. S. D.; TEN CATEN, A.; MOURA-BUENO, J. M.; CANCIAN, L. C.; PEDRON, F. A.; SCHENATO, R. B. Edaphic and Topographic factors and their relationship with dendrometric variation of Pinus taeda L. in a high altitude subtropical climate. Revista Brasileira de Ciência do Solo, Viçosa, v. 42 , p.1 16, 2018.

HUSS, J.; DOBNER JR, M. Einfluss von Ausgangspflanzendichte und Durchforstung auf Wachstum und wirtschaftlichen Ertrag von Weihrauchkiefer (Pinus taeda) in Südbrasilien. Allgemeine Forst und Jagdzeitung, Bad Orb, v. 190, n.1/2, p. 1 - 21, 2020.

IBÁ - Indústria Brasileira de Árvores. Relatório Ibá 2019. Elaborado por Pöyry Consultoria em Gestão de Negócios Ltda., 2019, 80 p.

MAMO, N.; STERBA, H. Site index functions for Cupressus lusitanica at Munesa Shashemene, Ethiopia. Forest Ecology and Management, Amsterdam v. 237, p. 429 - 435, 2006.

MARTINS, A. P. M.; MACHADO, S. A.; FIGUEIREDO FILHO, A.; DALLA CORTE, A. P.; GORENSTEIN, M. R. Efeito da idade na forma do fuste de Araucaria angustifolia na região Centro-Sul do Paraná. Pesquisa Florestal Brasileira, Colombo, v. 37, n. 90, p. 109 - 117, 2017.

MILLER, J. T.; KNOWLES, F. B. Introduced forest trees in New Zealand: recognition, role, and seed source. 9. The cypresses. $3^{\mathrm{a}}$ ed., 1996, Rotorua, New Zealand, $40 \mathrm{p}$.

MOYA, R.; MUNOZ, F. Physical and mechanical properties of eight fast growing plantation species in Costa Rica. Journal of Tropical Forest Science, New York, v. 22, p. 317 - 328, 2010.

NGUGI, M. R.; MASON, E. G.; WHYTE, A. G. D. New growth models for Cupressus lusitanica and Pinus patula in Kenya. Journal of Tropical Forest Science, New York, v. 12, n. 3, p. 524 - 541, 2000.

OKINO, E. Y. A.; SANTANA, M. A. E.; ALVES, M. V. S.; MELO, J. E.; CORADIN, V. T. R.; SOUZA, M. R.; TEIXEIRA, D. E.; SOUZA, M. E. Technological characterization of Cupressus spp. wood. Floresta e Ambiente, Seropédica, v. 17, n. 1, p. 1 - 11, 2010.

PUKAllA, T.; POHJONEN, V. Yield of Cupressus lusitanica in Ethiopia. Silva Fennica, Helsinki, v. 27, n. 3, p. 195 - 207, 1993.

SCHUCHOVSKI, M. S.; ARCE, J. E.; OLIVEIRA, E. B. Altura dominante e índice de sítio para Pinus taeda em dois polos de desenvolvimento florestal no sul do Brasil. Scientia Forestalis, Piracicaba, v. 47, n. 121, p. 92 - 104, 2019.

SHIMIZU, J. Y.; PINTO JR., J. E.; RIBATSKI, G. Cipreste para madeira: alto incremento volumétrico com material genético apropriado. Boletim de Pesquisa Florestal, Colombo, v. 30/31, p. 3 - 17, 1995.

TESHOME, T.; PETTY, J. A. Site index equation for Cupressus lusitanica stands in Munessa forest, Ethiopia. Forest Ecology and Management, Amsterdam, v. 126, p. 339 - 347, 2000.

VIVIAN, M. A.; NUNES, G. C.; DOBNER JR., M.; MODES, K. S.; GROSSKOPF, E. J.; BELINI, U. L. Natural durability of Cupressus lusitanica, Cryptomeria japonica and Pinus taeda woods in field trial. Floresta, Curitiba, v. 50, n. 3, p. $1603-1612,2020$.

WATT, M. S.; PALMER, D. J.; DUNGEY, H.; KIMBERLEY, M. O. Predicting the spatial distribution of Cupressus lusitanica productivity in New Zealand. Forest Ecology and Management, Amsterdam, v. 258, p. 217 - 223, 2009. 